\title{
KLASIFIKASI PEMINJAMAN NASABAH BANK MENGGUNAKAN METODE NEURAL NETWORK
}

\author{
Nur Hadianto'; Hafifah Bella Novitasari²; Ami Rahmawati \\ Ilmu Komputer \\ STMIK Nusa Mandiri Jakarta \\ www.nusamandiri.ac.id \\ 1'dion.adiyanto@gmail.com; ${ }^{2}$ hafifah.bella@gmail.com; ${ }^{3}$ amirahmawati095@gmail.com
}

\begin{abstract}
Payment of loans that experience difficulties in repayment or often called bad credit is a very detrimental thing for the bank, with the occurrence of bad credit the bank does not have the maximum ability to make money for investment. Choosing the right customer must go through the right analysis because the decision to approve or disagree with the loan is the main point that determines the possibility of bad credit. This study aims to classify eligible customers to obtain loans by taking into account existing parameters such as age, total income, number of families, monthly expenditure average, education level and others. This study uses a data mining classification method with a neural network model, to assess the accuracy of data processing using rapid miners then proceed with measurements using confusion matrix, ROC curve. The results of the neural network algorithm after going through confusion matrix testing, the ROC curve shows a very high accuracy value, and the dominant value of AUC and algorithm. The accuracy value is $98.24 \%$ with AUC of 0.979 .
\end{abstract}

Keywords: Loan, Classification, Neural Network, Data Mining, Rapid Miner, Backpropagation

Abstrak - Pembayaran pinjaman yang mengalami
kesulitan dalam pengembalian atau sering disebut
kredit macet merupakan sebuah hal yang sangat
merugikan bagi pihak bank, dengan terjadinya
kredit macet bank tidak memiliki kemampuan yang
maksimal dalam melakukan perputaran uang
untuk investasi. Pemilihan nasabah yang tepat
harus melalui analisa yang matang karena
keputusan untuk menyetujui atau tidak menyetujui
pinjaman adalah poin utama yang menentukan
kemungkinan terjadinya kredit macet. Penelitian
ini bertujuan untuk mengklasifikasi nasabah yang
layak untuk mendapatkan pinjaman dengan
memperhitungkan parameter yang ada seperti
usia, jumlah pendapatan, jumlah keluarga, rata-
rata pengeluaran perbulan tingkat pendidikan dan
lainnya. Penelitian ini menggunakan metode
klasifikasi data mining dengan model neural
network, untuk menilai akurasi pengolahan data network, untuk menilai akurasi pengolahan data menggunakan rapid miner kemudian dilanjutkan dengan pengukuran menggunakan confusion matrix, kurva ROC. Hasil algoritma neural network setelah melalui pengujian confusion matrix, kurva ROC menunjukkan nilai akurasi yang sangat tinggi, dan nilai dominan AUC dan algoritma. Nilai akurasi adalah 98,24\% dengan AUC sebesar 0,979

Kata Kunci: Pinjaman, Klasifikasi, Neural Network, Data Mining, Rapid Miner, Backpropagation.

\section{PENDAHULUAN}

Menurut Undang-Undang Perbankan Nomor 10 Tahun 1998, kredit adalah penyediaan uang atau tagihan yang dapat dipersamakan dengan itu berdasarkan persetujuan atau kesepakatan pinjam - meminjam antar bank dengan pihak lain yang mewajibkan pihak peminjam melunasi hutangnya setelah jangka waktu tertentu dengan pemberian bunga (Marhumi, 2017), dalam menjalankan bisnisnya penting bagi bank dan lembaga pembiayaan untuk mengevaluasi resiko kredit dilakukan dimuka bagi konsumen. Sebuah model yang baik bagi penilaian kredit akan membantu bank dan lembaga pembiayaan membuat keputusan yang tepat dalam rangka menghindari potensi besarnya resiko (Defu, Stephen, \& Zhimei, 2008), Penilaian kredit sebagai teknik penilaian merupakan instrumen penting dalam industri keuangan dan perbankan (Wang, Lai, \& Niu, 2011).

Besarnya jumlah kredit yang disalurkan akan menentukan keuntungan yang diperoleh. Akan tetapi tidak berarti bahwa jumah kredit yang disalurkan besar akan memberikan keuntungan yang besar pula (Marhumi, 2017). Dewasa ini, masih banyak perusahaan keuangan atau bank mengalami kesulitan untuk meminjamkan asset berupa pinjaman (loan) kepada nasabah yang terpercaya dan sesuai ketentuan (Arun, Ishan, \& Sanmeet, 2016). Dalam proses pemberian pinjaman selama ini yang dilakukan oleh bank, meskipun melalui analisa kredit yang berjenjang masih saja terdapat permasalah yang timbul salah 
satunya adalah para calon peminjam melakukan berbagai macam cara agar pinjamannya dapat disetujui oleh pihak Bank. Hal ini lah yang menyebabkan tingkat kredit macet menjadi meningkat (Iriadi \& Nuraeni, 2016). Penyebab lainnya antara lain kurang akuratnya pegawai Bank dalam menganalisa calon debitur (Iriadi \& Nuraeni, 2016). Salah satu metode yang dapat digunakan adalah pendekatan Machine Learning (Putri, 2018).

Data mining adalah proses menemukan korelasi, pola, dan tren baru yang bermakna dengan menyaring sejumlah besar data yang disimpan dalam repositori, menggunakan teknologi pengenalan pola serta teknik statistik dan matematik (Larose, 2005), jika data mining berfokus pada penggunaan program untuk membantu pembelajaran manusia terhadap data maka metode pembuatan program yang dapat belajar disebut machine learning , berbeda dengan program komputer yang biasa, machine learning adalah program yang dirancang untuk mampu belajar sendiri (Putri, 2018). Metode klasifikasi adalah salah satu metode yang paling sering digunakan, di dalam metode klasifikasi salah satu teknik yang digunakan adalah Neural Network yang sering digunakan untuk menyelesaikan masalahmasalah yang rumit dan berkaitan dengan identifikasi input, prediksi, pengenalan pola dan sebagainya (Windarto, 2017).

Dikarenakan hal tersebut maka dalam penelitian ini penulis akan menggunakan metode klasifikasi menggunakan teknik Neural Network dalam menentukan klasifikasi peminjaman bagi nasabah yang memiliki peluang tinggi untuk menjadi nasabah peminjam.

\section{BAHAN DAN METODE}

\section{a. Sumber data}

Data yang digunakan dalam penelitian ini adalah data sekunder yang diperoleh dari machine learning repository dengan alamat web http://www.kaggle.com dengan jumlah data 5000 observasi mengenai perilaku nasabah pada bank dalam periode tertentu.

\section{b. Variabel Penelitian}

Dalam penelitian ini kita akan menggunakan dataset sebanyak 5000 data yang terdiri dari 14 variabel yang dapat diihat pada Tabel 1

Tabel 1 : Variabel Penelitian

\begin{tabular}{|c|c|c|c|c|c|c|c|}
\hline 1 & ID & $\begin{array}{l}\text { Identitas } \\
\text { nasabah berupa } \\
\text { nomor urut }\end{array}$ & Kuantitatif & & & \multirow[t]{2}{*}{$\begin{array}{l}\text { oleh } \\
\text { UniversalBank } \\
0 . \text { Tidak } \\
\text { 1. Ya }\end{array}$} & \\
\hline \multirow[t]{2}{*}{2} & Age & Usia nasabah & Kuantitatif & & & & \\
\hline & & (tahun) & & \multirow[t]{2}{*}{14} & \multirow{2}{*}{$\begin{array}{l}\text { Personal } \\
\text { Loan } \\
\text { (Target) }\end{array}$} & \multirow{2}{*}{$\begin{array}{l}\text { Pembelian } \\
\text { peminjaman } \\
\text { aset }\end{array}$} & \multirow[t]{2}{*}{ Kuantitatif } \\
\hline 3 & Experience & $\begin{array}{l}\text { Pengalaman } \\
\text { profesional }\end{array}$ & Kuantitatif & & & & \\
\hline
\end{tabular}

\begin{tabular}{|c|c|c|c|}
\hline & & $\begin{array}{l}\text { nasabah } \\
\text { (tahun) }\end{array}$ & \\
\hline 4 & Income & $\begin{array}{l}\text { Pendapatan per } \\
\text { tahun nasabah } \\
(\$ 000)\end{array}$ & Kuantitatif \\
\hline 5 & ZIP Code & $\begin{array}{l}\text { Kode ZIP (Zone } \\
\text { Improvement } \\
\text { Plan) atau kode } \\
\text { pos alamat } \\
\text { nasabah }\end{array}$ & Kuantitatif \\
\hline 6 & Family & $\begin{array}{l}\text { Jumlah anggota } \\
\text { keluarga } \\
\text { nasabah (tanpa } \\
\text { nasabah) }\end{array}$ & Kuantitatif \\
\hline 7 & CCAvg & $\begin{array}{l}\text { Rata-rata } \\
\text { pengeluaran } \\
\text { nasabah } \\
\text { menggunakan } \\
\text { kartu kredit per } \\
\text { bulan }(\$ 000)\end{array}$ & Kuantitatif \\
\hline 8 & Education & $\begin{array}{l}\text { Tingkat } \\
\text { pendidikan } \\
\text { nasabah } \\
\text { 1. Belum lulus } \\
\text { kuliah } \\
\text { 2. Sudah lulus } \\
\text { kuliah } \\
\text { 3. Profesional }\end{array}$ & Kuantitatif \\
\hline 9 & Mortgage & $\begin{array}{l}\text { Harga } \\
\text { penggadaian } \\
\text { rumah nasabah } \\
(\$ 000)\end{array}$ & Kuantitatif \\
\hline 10 & $\begin{array}{l}\text { Securities } \\
\text { Account }\end{array}$ & $\begin{array}{l}\text { Kepemilikan } \\
\text { nasabah akan } \\
\text { akun keamanan } \\
\text { bersama bank } \\
0 . \text { Tidak } \\
\text { 1. Ya }\end{array}$ & Kuantitatif \\
\hline 11 & CD Account & $\begin{array}{l}\text { Kepemilikan } \\
\text { nasabah akan } \\
\text { sertifikat } \\
\text { deposit } \\
\text { bersama bank } \\
0 . \text { Tidak } \\
\text { 1. Ya }\end{array}$ & Kuantitatif \\
\hline 12 & Online & $\begin{array}{l}\text { Penggunaan } \\
\text { nasabah akan } \\
\text { fasilitas online } \\
\text { banking } \\
0 . \text { Tidak } \\
\text { 1. Ya }\end{array}$ & Kuantitatif \\
\hline 13 & CreditCard & $\begin{array}{l}\text { Penggunaan } \\
\text { nasabah akan } \\
\text { kartu kredit } \\
\text { yang } \\
\text { dikeluarkan } \\
\text { oleh } \\
\text { UniversalBank } \\
\text { 0. Tidak } \\
\text { 1. Ya }\end{array}$ & Kuantitatif \\
\hline 14 & $\begin{array}{l}\text { Personal } \\
\text { Loan } \\
\text { (Target) }\end{array}$ & $\begin{array}{l}\text { Pembelian } \\
\text { peminjaman } \\
\text { aset }\end{array}$ & Kuantitatif \\
\hline
\end{tabular}




\begin{tabular}{ll}
\hline (personal loan) \\
oleh nasabah \\
0. Tidak \\
1. Ya \\
\hline
\end{tabular}

Sumber : (Hadianto et al., 2019)

\section{c. Neural Network: Multi Layer Perceptron}

Neural network adalah pemrosesan informasi sistem. Secara umum neural network dapat dianggap sebagai sistem kotak hitam yang menerima input dari lingkungan dan menghasilkan output. neural network mengandung elemen pemrosesan dan pembobotan yang saling terhubung. Setiap lapisan dalam jaringan berisi oleh kelompok elemen pemrosesan seperti yang ditunjukkan pada gambar.1 (Fadly, Uddin, \& Sutarto, 2002)

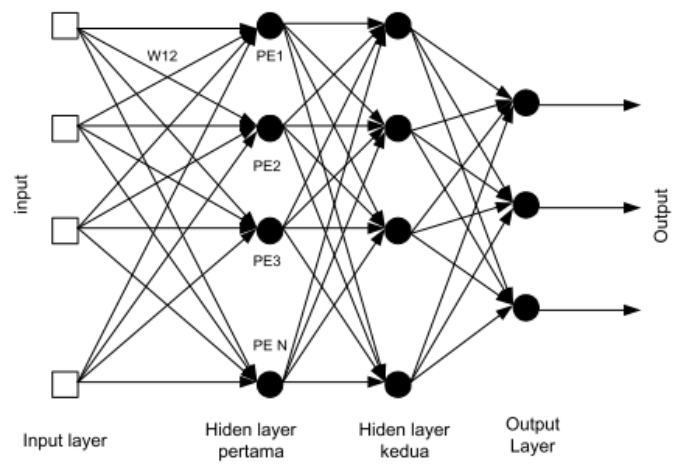

Sumber: (Fadly et al., 2002)

Gambar 1. Multi Layer Perceptron Neural Networks

Setiap elemen pemrosesan mengumpulkan nilai dari semua input yang terhubung ke elemen pemrosesan dan menghasilkan output melalui operasi matematika (perkalian operasi). Ada tiga lapisan yang membangun neural network, yaitu lapisan input, lapisan tersembunyi, dan lapisan keluaran. (Fadly et al., 2002)

\section{d. Artificial Neural Network}

Artificial Neural Network (Jaringan Syaraf Tiruan) adalah model non-linear yang kompleks, dibangun dari komponen yang secara individu berperilaku mirip dengan model regresi. Jaringan syaraf tiruan dapat divisualisasikan dengan grafik, dan beberapa sub-grafik beberapa memiliki perilaku yang sama dengan grafik sebelumnya. Meskipun struktur dari jaringan saraf secara eksplisit dirancang terlebih dahulu, pengolahan jaringan saraf ini tidak untuk menghasilkan hipotesis (berbagai neuron dan pengolahan lainnya terstruktur dalam jaringan) berkembang selama proses pembelajaran. Hal ini memungkinkan neuron yang membentuk jaringan akan digunakan sebagai pemecahan masalah dari "program itu sendiri". (Yalidhan, 2018)

\section{e. Arsitektur Backpropagation}

Algoritma back-propagation adalah algoritma yang paling populer dalam pembelajaran jaringan saraf tiruan. Algoritma ini didasarkan pada aturan pembelajaran dengan koreksi kesalahan (Fadly et al., 2002). Pembelajaran kesalahan-koreksi pada back-propagation dibagi dalam dua cara utama; pergerakan maju dan mundur. Di depan, vektor input diterapkan pada layer input di setiap jaringan kemudian mempengaruhi semua jaringan, lapis demi lapis. Output dari jaringan adalah respon dari jaringan saraf. Bobot di setiap lapisan di depan adalah tetap. Gambar dan persamaan pembelajaran maju ditunjukkan dalam gambar 2 dan persamaan 1 dan 2 (Fadly et al., 2002)

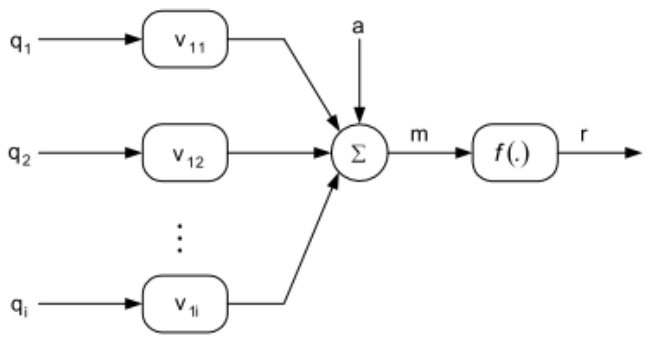

Sumber: (Fadly et al., 2002)

Gambar 2. Forward Learning Neural Network $m=V_{q}+a$

$$
r=f(m)
$$

Pada bagian belakang semua pembobotan di setiap lapisan berubah berdasarkan aturan koreksi kesalahan. Kesalahan adalah pengurangan respons jaringan dan target keinginan. Kesalahan ini diterapkan secara mundur ke semua jaringan yang telah dilewati atau dengan cara yang berlawanan dari struktur jaringan karenanya disebut sebagai "back - propagation". Semua bobot dalam jaringan diperbaiki dan respon jaringan bergerak menuju sasaran. Teknik pembelajaran back-propagation pada koreksi error menggunakan metode gradient descent. Prinsip metode ini adalah efisiensi turunan parsial dari fungsi aktivasi di setiap elemen untuk menyesuaikan perubahan bobot pada setiap input.

$$
V(k+1)=V(k)-\eta \frac{\partial E}{\partial m} \frac{\partial m}{\partial V}
$$

Dimana

$$
\begin{gathered}
E=\frac{1}{2} e^{T}(k) e(k) . . \\
e(k)=d(k)-r(k)
\end{gathered}
$$

Dimana

$e(k)=$ Kesalahan antara target dan respon

$d(k)=$ Target yang diinginkan

$$
\eta=\text { Learning rate }
$$




\section{f. Percobaan dan Pengujian Model}

Dataset yang dimiliki akan dibagi 2, sebagian akan digunakan sebagai training set dan sebagian akan digunakan sebagai data testing set, kemudian data training tersebut akan dimasukkan dalam sebuah metode neural network dengan backpropagation program menggunakan tools Rapid Miner.

\section{g. Evaluasi dan Validasi Hasil}

Evaluasi dan validasi dilakukan untuk membahas hasil pengamatan dan analisa yang dilakukan terrhadap penelitian ini menggunakan Neural Network di Rapid Miner. Pengujian yang didapat dari metode confusion matrix adalah akurasi sedangkan pengujian yang didapat dari metode ROC CURVE (AUC) adalah gambaran kurva yang memisahkan antara kelas berbeda.

\section{Cross Validation}

Cross validation adalah prosedur untuk memperkirakan generalisasi kinerja dalam sebuah metode permodelan. Cross-validation adalah metode yang paling sering digunakan untuk evaluasi kinerja prediktif dari sebuah model, yakni model yang diberikan sebelumnya atau model yang telah dikembangkan oleh prosedur permodelan (Yadav \& Shukla, 2016). Data biasanya akan dibagi menjadi dua bagian pada bagian pertama dilakukan pelatihan sementara pada bagian lainnya dilakukan uji kinerja, skema pelatihan dan pengujian bekerja dengan baik pada model klasifikasi di dalam machine learning, beberapa record dalam dataset dijadikan data training untuk dilatih sementara record lainya di dalam dataset digunakan sebagai data testing, hal tersebut adalah prinsip dasar dari cross validation, karena hal tersebutlah cross-validation sangat diterima dalam komunitas data mining dan machine learning dan berfungsi sebagai prosedur standard untuk pemilihan model atau pemilihan prosedur permodelan, (Yadav \& Shukla, 2016)

II. Pengukuran menggunakan ROC Curve
Pengukuran hasil validasi dengan menggunakan ROC Curve dan Confusion matrix sampai mendapatkan tingkat akurasi yang tertinggi. ROC Curve adalah Kurva ROC banyak digunakan para peneliti untuk menilai hasil prediksi Kurva ROC menggambarkan kinerja klasifikasi tanpa memperhatikan distribusi kelas atau kesalahan, pada sumbu vertical menggambarkan nilai positif (TP) dan sumbu horizontal menandakan nilai negative (FP) .(Ir. Adi Sucipto, n.d.).. ditunjukkan dalam gambar 3

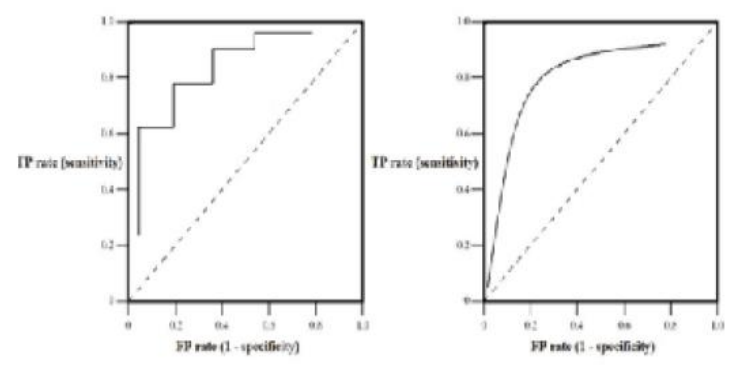

Sumber : (Sucipto, 2012)

Gambar 3. Contoh Grafik ROC

Garis diagonal yang membelah ruang ROC menggambarkan ruang diatas garis diagonal menandakan klasifikasi baik dan ruang dibawah garis diagonal menandakan klasifikasi buruk, sementara tebakan yang benar-benar acak terdapat pada sepanjang garis diagonal mulai dari kiri bawah sampai dengan kanan atas

Sebuah metode umum untuk menghitung daerah dibawah kurva ROC adalah Area Under Curve (AUC) dimana bidang yang berada dibawah kurva mempunyai nilai yang selalu berada pada nilai 0,0 dan 1,0. Namun yang menarik untuk dihitung adalah yang mempunyai luas diatas 0,5 , semakin tinggi luasnya maka akan semakin baik seperti petunjuk yang disajikan berikut ini (Ir. Adi Sucipto, n.d.)::

$$
\begin{aligned}
& >0.9-1.00=\text { klasifikasi yang sangat baik } \\
& >0.8-0.9=\text { klasifikasi baik } \\
& >0.7-0.8=\text { klasifikasi rata-rata } \\
& >0.6-0.7=\text { klasifikasi rendah } \\
& >0.5-0.6=\text { kegagalan }
\end{aligned}
$$

\section{Pengukuran menggunakan confusion matrix}

Pengukuran terhadap kinerja suatu sistem klasifikasi merupakan hal yang penting. Kinerja sistem klasifikasi menggambarkan seberapa baik sistem dalam mengklasifikasikan data. Confusion matrix merupakan salah satu metode yang dapat digunakan untuk mengukur kinerja suatu metode klasifikasi. Pada dasarnya confusion matrix mengandung informasi yang membandingkan hasil klasifikasi yang dilakukan oleh sistem dengan hasil klasifikasi yang seharusnya. (E. Prasetyo, 2012)

$$
\text { Pada pengukuran kinerja }
$$
menggunakan confusion matrix, terdapat 4 (empat) istilah sebagai representasi hasil proses klasifikasi. Keempat istilah tersebut adalah True Positive (TP), True Negative (TN), False Positive (FP) dan False Negative (FN). Nilai True Negative (TN) merupakan jumlah data negatif yang terdeteksi dengan benar, sedangkan False Positive (FP) merupakan data negatif namun terdeteksi sebagai data positif. Sementara itu, True Positive (TP) merupakan data positif yang 
terdeteksi benar. False Negative(FN) merupakan kebalikan dari True Positive, sehingga data positif, namun terdeteksi sebagai data negatif.

Pada jenis klasifikasi binary yang hanya memiliki 2 keluaran kelas, confusion matrix dapat disajikan seperti pada Tabel 2 (Sokolova \& Lapalme, 2009)

Tabel 2. Confusion Matrix

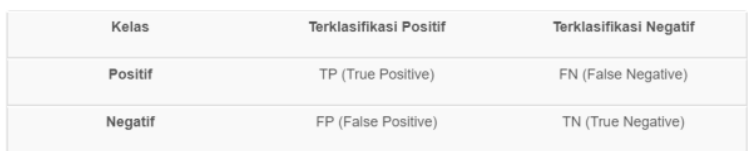

Sumber : (Hadianto et al., 2019)

Dari tabel diatas kita dapat melihat nilai akurasi, presisi dan recall didapat dari nilai True Positive (TP), True Negative (TN), False Positive (FP) dan False Negative (FN), nilai akurasi menggambarkan seberapa akurat dan efektifitas sistem secara keseluruhan dalam mengklasifikasikan data secara benar, perhitungan akurasi dinyatakan dalam persamaan 5 (Sokolova \& Lapalme, 2009)

Akurasi $=\frac{T P+T N}{T P+T N+F P+F N} \times 100 \%$

\section{HASIL DAN PEMBAHASAN}

\section{Hasil Penelitian}

Pada bagian ini akan membahas hasil implementasi penggunaan Neural Network pada penentuan klasifikasi peminjaman nasabah pada sebuah bank dengan menggunakan metode backpropagation, Analisa difokuskan pada pengaruh struktur neural network, tingkat pembelajaran (learning rate) neural network, dan momentum neural network, dalam penelitian ini menggunakan dataset sebanyak 5000 data.

Dalam penelitian untuk mendapatkan struktur neural network yang optimal kami melakukan beberapa ujicoba perubahan struktur dengan tingkat pembelajaran (learning rate), training cycles dan momentum yang sama yakni learning rate $=0.0 .1$, training cycles $=500$ dan momentum $=0.1$, pertama kali kami mencoba struktur $12-7-3-1$ artinya struktur tersebut memiliki 12 input, 7 neuron pertama yang tersembunyi, 3 neuron kedua yang tersembunyi dan 1 output, kemudian kami mencoba beberapa struktur yang lain seperti $12-20-8-1,12-15-$ $8-1,12-10-5-1,12-7-3-1$, dari semua struktur yang dicoba tidak terdapat perbedaan yang signifikan hanya selisih 0 (nol) koma sekian, akan tetapi dari seluruh struktur yang sudah kami coba kami menemukan bahwa struktur 12 - $15-8$ - 1 merupakan struktur yang paling adaptif dengan akurasi $98.24 \%$, struktur $12-15-8-1$ adalah seperti pada gambar 4. dibawah ini.

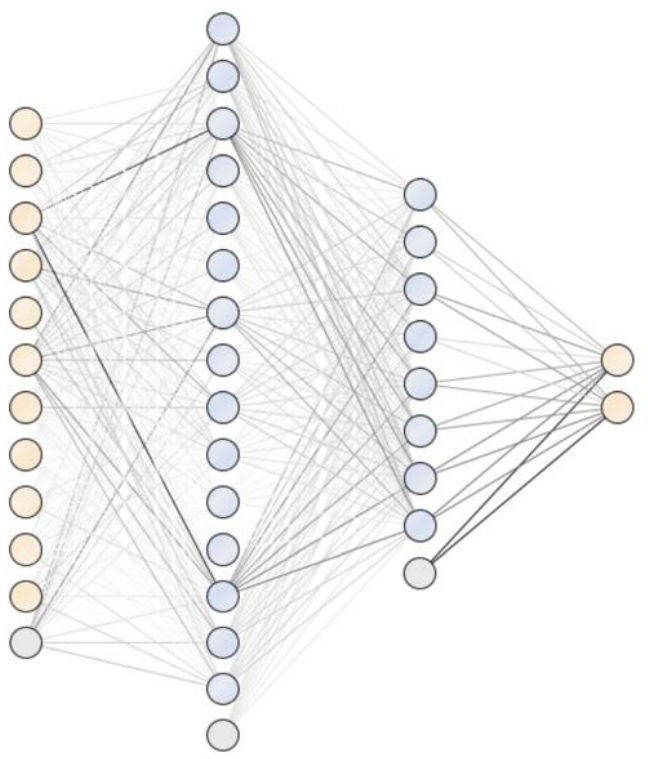

Sumber : (Hadianto et al., 2019)

Gambar 4. Neural Network Struktur 12 - 15 - 8 - 1

Tingkat akurasi yang didapatkan dari hasil ujicoba ini adalah sebesar 98.24\% +/- 0.62\% dan AUC sebesar $0.979+/-0.0 .14$ seperti pada gambar yang disajikan dari Performance Vector seperti pada gambar 5. dibawah ini.

\section{PerformanceVector}

PerformanceVector:

accuracy: 98.248 +/ -0.628 (micro average: 98.248 )

ConfusionMatrix:

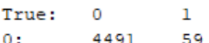

$1: 29$

AUC: $0.979+/-0.014$ (micro average: 0.979 ) (positive class: 1)

Sumber : (Hadianto et al., 2019)

Gambar 5. Performance Vector Neural Network

\section{Pembahasan penelitian}

Setelah pada tahap proses pengumpulan data dan pemilahan atribut yang akan digunakan di dalam dataset maka langkah selanjutnya adalah kita harus memasukkan datanya terlebih dahulu dengan fungsi read excel kedalam tools rapid miner lalu pembuatan permodelan neural network menggunakan data sebanyak 5000, tahapan proses dimulai dengan tahap permodelan kemudian memasuki tahap learning guna memproses datatraining dengan ujicoba struktur, training cycles, learning rate, momentum kemudian diakhiri dengan testing untuk melihat hasil.

1. Proses Permodelan

Proses ini menggunakan cross validation untuk melakukan pengujian model setelah sebelumnya 
model telah dibaca dengan operator read excel, seperti pada gambar 6 .

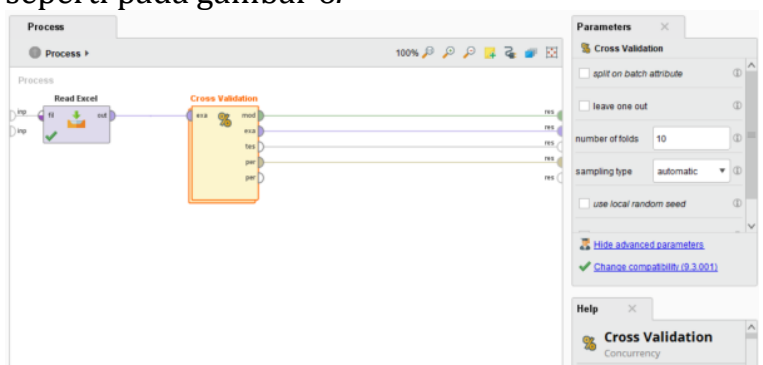

Sumber : (Hadianto et al., 2019)

Gambar 6. Permodelan Neural Network

Pada gambar diatas dilakukan proses pengujian model yang telah dibaca menggunakan operator read excel, data yang telah dibaca tersebut kemudian dimasukkan kedalam operator cross validation, dalam penelitian ini cross validation yang digunakan sebesar 10 fold validation.

2. Proses Training

Proses selanjutnya yang dilakukan adalah proses training, proses ini dilakukan di dalam operator cross validation dengan menggunakan algoritma neural network, dengan algoritma ini maka data akan dibagi menjadi 2, bagian pertama digunakan sebagai datatraining dan bagian kedua digunakan sebagai datatesting, seperti pada gambar 7 dibawah ini.

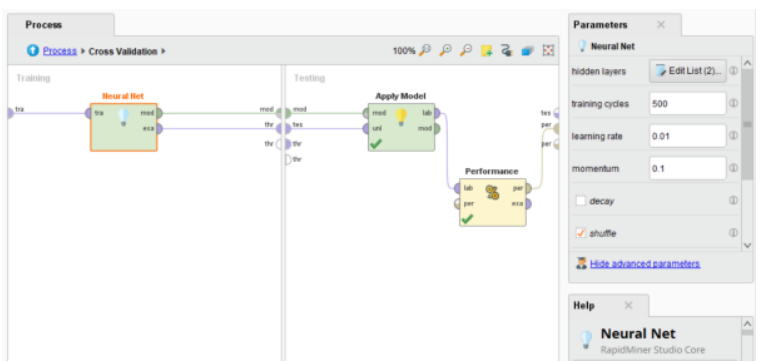

Sumber : (Hadianto et al., 2019)

Gambar 7. Proses Training Neural Network

Pada gambar diatas proses training dilakukan menggunakan operator neural network, training diatas menggunakan struktur $12-15-8-1$ dengan training cycles sejumlah 500, learning rate 0.01 dan momentum 0.1 .

\section{Proses Testing}

Tahapan terakhir dari proses ini setelah dilakukan training adalah testing terhadap dataset menggunakan fungsi backpropagation yang telah dilakukan pada datatraining sebelumnya, proses testing ini dilakukan dengan cara insert apply model dan performance dengan main criterion accuracy dan AUC, seperti pada gambar 8 dibawah ini.

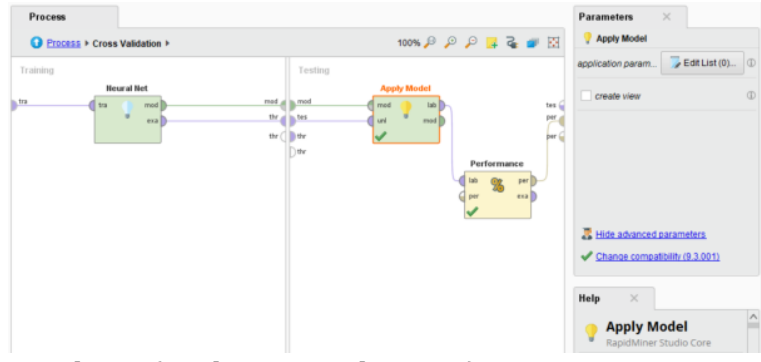

Sumber : (Hadianto et al., 2019)

Gambar 8. Proses Testing Neural Network

4. Hasil Testing

Hasil dari training dan juga testing data terhadap 5000 data nasabah Bank yang mengajukan pinjaman dapat kita lihat pada Performance Vector seperti pada gambar 9 dibawah ini.

\section{PerformanceVector}

Performancevector:

accuracy: $98.24 \%+/-0.62 \%$ (micro average: 98.24 \%

Hasil testing menggunakan algoritma neural network menunjukkan performance accuracy yang didapat sebesar $98.24 \%$.

5. Hasil Uji ROC Curve

Hasil dari training dan juga testing data menggunakan neural network menampilkan grafik ROC dengan nilai AUC (Area Under Curve) sebesar , hasil tersebut dapat dilihat seperti pada gambar 10 dibawah ini.

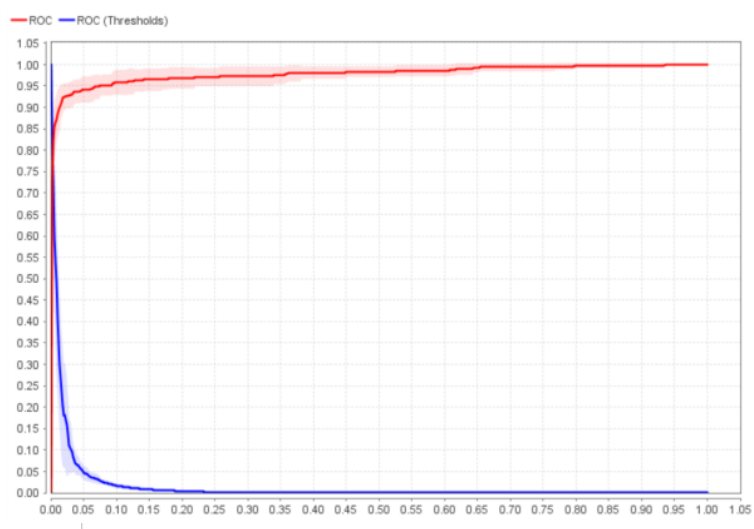

ADC: $0.979+/-0.014$ (micro average: 0.979 ) (positive class: 1)

Sumber : (Hadianto et al., 2019)

Gambar 10. Nilai AUC pada grafik ROC Neural Network.

Dari gambar diatas kita dapat melihat bahwa nilai sebesar 0.979. termasuk dalam kategori "klasifikasi yang sangat baik" karena data tersebut berada diantara range $0.9-1.0$

6. Hasil Uji Confusion Matrix

Tabel dari confusion matrix hasil pengolahan dataset menggunakan algoritma 
backpropagation pada neural network adalah seperti pada gambar 11 dibawah ini.

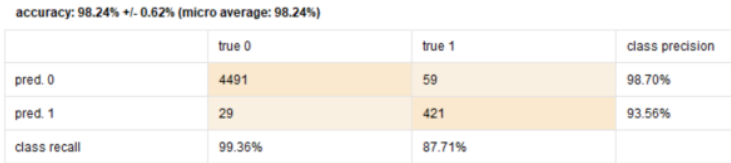

Dari parameter TP, FP, FN dan TN pada gambar diatas kita dapat menghitung secara manual nilai akurasi dengan menggunakan rumus pada persamaan 6, 7 dan 8 . sebagai berikut.

$$
\text { Akurasi }=\frac{T P+T N}{T P+T N+F P+F N} x 100 \% \text {. }
$$

(Sokolova \& Lapalme, 2009)

True Positive $(t p)=4491$ record

False Negative $(f n)=59$ record

True Negative $(t n)=421$ record

False Positive $(\mathrm{fp})=29$ record

$\mathrm{TP}=4491 \quad \mathrm{FN}=59$

$$
\mathrm{FP}=29 \quad \mathrm{TN}=421
$$

Akurasi $=\frac{(4491+421)}{(4491+421+29+59)} \times 100 \%$

Akurasi $=\frac{4912}{5000} \times 100 \%=98.24 \%$

Dari hasil klasifikasi menunjukkan bahwa, tingkat akurasi dengan menggunakan algoritma neural network adalah sebesar 98,24\%

\section{KESIMPULAN}

Berdasarkan penelitian yang telah dilakukan menggunakan tools rapid miner 9.0 terhadap data nasabah Bank sejumlah 5000 dataset yang didapat dari machine learning repository dengan alamat web http://www.kaggle.com yang diuji dengan algoritma backpropagation dalam Neural Network menggunakan struktur $12-15-8-1$, training cycles sejumlah 500, learning rate 0.01 dan momentum 0.1 menghasilkan nilai akurasi = 98.24\%, dengan AUC sebesar =0,979 yang menunjukkan bahwa klasifikasi yang dihasilkan sangat baik, sehingga nasabah dengan parameter yang ada dapat diprediksi menggunakan pola ini untuk menentukan nasabah yang layak diberikan pinjaman dari pihak Bank.

\section{REFERENSI}

Arun, K., Ishan, G., \& Sanmeet, K. (2016). Loan Approval Prediction based on Machine Learning Approach. 18(3), 2016. https://doi.org/10.9790/0661-1803017981

Defu, Z., Stephen, C. H. L., \& Zhimei, Y. (2008). A decision tree scoring model based on genetic algorithm and K-means algorithm. Proceedings - 3rd International Conference on Convergence and Hybrid Information
Technology, ICCIT 2008, 1, 1043-1047. https://doi.org/10.1109/ICCIT.2008.110

Fadly, M., Uddin, N., \& Sutarto, H. Y. (2002). Flutter Suppression Using Neural Networks: Design and Implementation. (January 2017).

Hadianto, N., Novitasari, H. B., Rahmawati, A., Prasetyo, R., Miharja, J., \& Komputer, I. (2019). Klasifikasi peminjaman nasabah bank menggunakan metode neural network. 14(2), $1-7$.

Ir. Adi Sucipto, M. K. (n.d.). CREDIT PREDICTION WITH NEURAL NETWORK ALGORITHM Ir . Adi Sucipto, M. Kom. Sains and Technology Faculty Universitas Islam Nahdlatul Ulama Jepara. (15), 978-979.

Iriadi, N., \& Nuraeni, N. (2016). kajian penerapan metode klasifikasi data mining algoritma C4.5 untuk prediksi kelayakan kredit pada bank mayapada jakarta. Jurnal Teknik Komputer AMIK BSI (JTK), 2, 132-137.

Larose, D. T. (2005). Discovering Knowledge in Data. New Jersey: Johny Wiley \& Sons, Inc.

Marhumi, S. (2017). Analisis Manajemen Perkreditan Untuk Meningkatkan Profitabilitas Pada Bank Bni Wilayah Vii Makassar. Perspektif, 02(01), 2355-2538. Retrieved from www.journal.unismuh.ac.id/perspektif

Putri, C. B. (2018). Klasifikasi Nasabah Thera Bank Membeli Personal Loan Menggunakan Metode Klasifikasi Dalam Machine Learning.

Sokolova, M., \& Lapalme, G. (2009). A systematic analysis of performance measures for classification tasks. Information Processing and Management, 45(4), 427-437. https://doi.org/10.1016/j.ipm.2009.03.002

Sucipto, A. (2012). CREDIT PREDICTION WITH NEURAL NETWORK ALGORITHM Ir . Adi Sucipto, M. Kom. Sains and Technology Faculty Universitas Islam Nahdlatul Ulama Jepara. (15), 978-979.

Wang, Q., Lai, K. K., \& Niu, D. (2011). Green credit scoring system and its risk assessemt model with support vector machine. Proceedings 4th International Joint Conference on Computational Sciences and Optimization, CSO 2011, 284-287.

https://doi.org/10.1109/CSO.2011.143 
Windarto, A. P. (2017). Implementasi Jst Dalam Menentukan. Sains Komputer \& Informatika, 1(1), 12-23.

Yadav, S., \& Shukla, S. (2016). Analysis of k-Fold Cross-Validation over Hold-Out Validation on Colossal Datasets for Quality Classification. Proceedings - 6th International Advanced Computing Conference, IACC 2016, (Cv), 7883. https://doi.org/10.1109/IACC.2016.25

Yalidhan, M. D. (2018). Implementasi Algoritma Backpropagation Untuk Memprediksi Kelulusan Mahasiswa. Klik - Kumpulan Jurnal Ilmu Komputer, 5(2), 169. https://doi.org/10.20527/klik.v5i2.152 